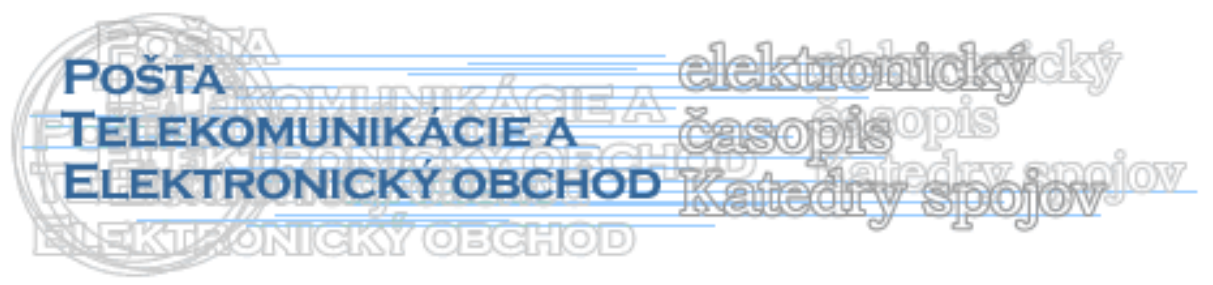

\title{
MERANIE SŤAŽNOSTÍ A REKLAMÁCIÍ
}

\author{
Lucia Madleňáková1, Radovan Madleňák ${ }^{2}$
}

\section{1. Úvod do problematiky}

Kvalita patrí v súčasnosti k rozhodujúcim kritériám, ktoré vo vel'kej miere ovplyvňujú vol'bu zákazníka pri výbere dodávatel'a tovaru či poskytovatel'a služby. Nepochybne je tiež jedným z rozhodujúcich faktorov konkurencieschopnosti podnikatel'ského subjektu na trhu.

Otázkami kvality poskytovaných služieb na spoločnom trhu sa začala zaoberat' Komisia Európske únie, ktorá predložila 11. júna 1992 tzv. „Zelenú knihu“ o rozvoji jednotného trhu poštových služieb a pre oblast' poštových služieb 2. júna 1993 oznámenie o smerniciach pre rozvoj poštových služieb spoločenstva. Problematika kvality poštových služieb býva zahrnutá do aj štúdií Európskej komisie, ktoré sa zaoberajú smermi rozvoja európskeho poštového odvetvia. Ciel'om takýchto štúdií je identifikovat', kvantifikovat' a vyhodnotit' rozvoj poštového odvetvia vo väzbe na zásady vyplývajúce z uplatňovania poštových smerníc, a to najmä z hl'adiska regulačného, ekonomického, z hl'adiska zákazníkov a zamestnancov, ako aj z hl'adiska kvality služby a technologického rozvoja.

Problematika kvality v poštových službách je prioritne zameraná na kategóriu služieb zahrnutých do súboru tzv. univerzálnej poštovej služby. Ide o služby chápané ako podsystém poštových služieb, ktorý je $\mathrm{v}$ Európskej únii zaradená medzi služby všeobecného ekonomického záujmu, ktorým je venovaná Biela kniha o službách všeobecného ekonomického záujmu (COM/2004)374 final) z 12.5.2004. Riešenie otázok kvality, zverejňovania výsledkov jej meraní a hodnotení a verejného riešenia konkurencieschopnosti, sa tak v spoločnosti často dotýka len poskytovatel'a univerzálnej služby, ktorému takéto povinnosti vyplývajú zo zákonnej úpravy. Ďalšie poštové podniky takúto povinnost' nemajú a deklarovanie kvality je len $\mathrm{v}$ polohe uverejňovania údajov $\mathrm{v}$ zmysle ich vlastného uváženia, čo je často zavádzajúce.

\subsection{St'ažnosti/reklamácie ako ukazovatel' kvality služieb}

„St’ažnost' je vyjadrenie nespokojnosti organizácii týkajúce sa vnímanej chyby jej produktov, služieb alebo politiky, alebo samostatného procesu vybavovania st'ažností, pričom sa explicitne alebo implicitne očakáva odpoved' alebo riešenie“. [4]

„St’ažovatel' je osoba, organizácia alebo ich predstavitel', ktorí sa st’ažujú na poskytované produkty/služby alebo organizáciu“. [4]

„Reklamácia je písomné podanie, ktorým zákazník uplatňuje zodpovednost’ voči organizácií za nekvalitne poskytnuté produkty, alebo služby nedodržaním povinností vyplývajúcich pre organizáciu, z obchodných podmienok alebo z uzatvorených zmlúv“. [4]

\footnotetext{
${ }^{1}$ Ing. Lucia Madleňáková, PhD., Katedra spojov, Fakulta prevádzky a ekonomiky dopravy a spojov, Žilinská univerzita v Žiline, email: Lucia.Madlenakova@fpedas.uniza.sk

2 doc. Ing. Radovan Madleňák, PhD., Katedra spojov, Fakulta prevádzky a ekonomiky dopravy a spojov,

Žilinská univerzita v Žiline, email: Radovan.Madlenak@fpedas.uniza.sk
} 
St’ažnosti môžu byt' tiež chápané ako žiadosti podané používatel'mi poštovej služby, aby deklarovali, že poskytnutá služba nesplnila normu, ktorú očakávali, alebo normu, ktorú musí poskytovatel' vždy splnit'. Každú jednu st’ažnost'/reklamáciu je potrebné prešetrit', aby sa overilo, či existuje skutočná nezhoda so službou, a je potrebné vždy odpovedat' st'ažovatel'om. Okrem toho je tiež možné st’ažnosti/reklamácie považovat' aj ako nástroj na ochranu používatel'ov, ak poskytovatel' nedodrží svoje vyhlásené záväzky a prísl'uby.

Poskytovatel' služby môže využit' st’ažnosti/reklamácie aj pri priebežnom zlepšovaní kvality poštovej služby. Úroveň st’ažností/reklamácii, ale aj dôvody podania st'ažností/reklamácií poskytujú dôležité informácie o spokojnosti jednotlivých používatel'ov s rôznymi stránkami poštovej služby. To si vyžaduje zaujat' zodpovedný prístup k efektívnemu vybavovaniu st’ažností/reklamácií na všetkých úrovniach v poštovom podniku. [4]

Každá st’ažnost'/reklamácia znamená pre organizáciu určitú komunikáciu so zákazníkom, v ktorej môže objavit' poučenie ale aj informácie. Aj vd'aka prehl'adnej a systematicky vedenej evidencii dôkladne preskúmaných zlyhaní produktu resp. služby je možné vytvorit' rozsiahlu informačnú základňu, ktorá bude neocenitel'ným pomocníkom pri priebežnom zavádzaní takých úprav a opatrení, ktoré vedú k neustálemu zlepšovaniu kvality poskytovaných služieb.

Každá jedna st'ažnost'/reklamácia, ktorú poštový podnik príjme sa musí klasifikovat'. Túto klasifikáciu je možné vykonat' na základe informácií, ktoré môže primerane poskytnút' st’ažovatel'. [4]

\subsection{Charakter a druhy st’ažností/reklamácií}

Opodstatnenost' st’ažností/reklamácií závisí od toho, čo ako je služba vyšpecifikovaná vo všeobecných obchodných podmienkach. Všetky st’ažnosti/reklamácie je potrebné zaznamenávat', vrátane informácie o uznaní opodstatnenosti/neopodstatnenosti. Do úvahy prichádzajú nasledujúce kategórie st’ažností/reklamácií:

- st’ažnosti/reklamácie na produkty/služby, ktoré sa poskytujú podl’a určených noriem,

- st’ažnosti/reklamácie na produkty/služby, kde sa chyba, na ktorú poukázal st’ažovatel', nedá overit',

- st'ažnosti/reklamácie na produkty/služby, kde sa chyba, na ktorú poukázal st’ažovatel' potvrdí.

Príčiny st’ažností/reklamácií - celkové príčiny st'ažností/reklamácií v globálnom poštovom odvetví sú zhodné vo všetkých kategóriách produktov a služieb. Odporúča sa, aby bol určitý počet základných kategórií, ktoré poštové organizácie zaznamenávajú oddelene na účel riadenia zlepšovania hlavnej služby pre použivatel'ov a pre zmluvné plány zlepšovania $\mathrm{s}$ hlavnými akcionármi vo vnútri aj mimo poštovej organizácie. Medzi základné odporúčané kategórie pre konkrétne st’ažnosti/reklamácie patria:

a) strata zásielky alebo jej časti,

b) oneskorenie (dodané po lehote, ale zásielka bola dodaná; oneskorenie sa má zaznamenat'),

c) poškodenie, ktoré sa týka obsahu, obalu alebo obálky,

d) nesprávne dodanie, na nesprávnu adresu alebo nesprávnemu adresátovi,

e) chyba doposielania, súvisiaca s trvalou alebo dočasnou zmenou adresy,

f) chyba týkajúca sa doručovania dobierky,

g) iné.

Do celkového počtu zaznamenaných st’ažností/reklamácí́ je nutné zahrnút' aj nasledujúce druhy st'ažností/reklamácií:

- prístup $\mathrm{k}$ informáciám o službách zákazníkom, napr. dostupnost' informácií o špecifikáciách produktov a o cenách; nesprávne poskytnuté informácie a rady alebo informácie o spôsobe spracovania st'ažností/reklamácií, 
- správanie a odbornost' zamestnancov,

- dostupnost' poštových služieb, napr. otváracie hodiny poštových prevádzkarní, čakanie $\mathrm{v}$ rade, čistota alebo prístup pre invalidných a telesne postihnutých l'udí,

- ako sa st’ažnosti/reklamácie vybavujú.

\section{Analýza súčasného stavu doma a v zahraničí}

Základom riešenia problematiky kvality je Smernica 97/67/ES, ktorá upravuje popri spoločných pravidlách rozvoja vnútorného trhu poštových služieb spoločenstva aj riešenie zlepšovania kvality služieb. V čl. 16 ukladá členským štátom povinnost' zabezpečit' stanovenie a zverejnenie normy kvality služieb, vzt'ahujúce sa na univerzálnu poštovú službu. Tieto normy majú byt' zamerané predovšetkým na lehoty, pravidelnost' a spol'ahlivost' služieb. Normy pre vnútroštátne poskytovanie služieb majú stanovit' členské štáty a v prípade medzinárodných služieb normy stanovuje príloha smernice. V čl. 16 smernice sa súčasne uvádza, že normy kvality možno d'alej prispôsobovat' technickému pokroku alebo rozvoju trhu v súlade so závermi Výboru pre poštovú smernicu, ktorého pôsobnost' upravuje čl. 21 uvedenej smernice. Smernica ukladá povinnost' vykonávat' sledovanie plnenia noriem externými orgánmi, ktoré nie sú žiadnym spôsobom spojené s poskytovatel'mi univerzálnych služieb. Normy kvality pre vnútroštátne služby, ktoré stanovujú členské štáty, musia byt' v súlade $\mathrm{s}$ normami stanovenými pre medzinárodné služby v rámci spoločenstva. $\mathrm{O}$ vnútroštátnych normách kvality informujú členské štáty Komisiu, ktorá ich zverejňuje rovnako ako normy pre medzinárodné služby.[2]

Regulácia kvality služby sa vzt'ahuje na poskytovatel'ov univerzálnej služby vo všetkých členských krajinách, kým povinnost' implementovat' monitorovací systém a zverejňovat' výsledky merania sa vzt'ahuje na konkurenčných licencovaných poštových operátorov len v niektorých členských krajinách (Belgicko, Portugalsko, Spojené král'ovstvo). Regulácia kvality sa prioritne zameriava na lehotu dopravy v najrýchlejšej štandardnej kategórie US (normy EN 13850). Smernica vyžaduje stanovenie noriem kvality pre všetky univerzálne služby, čo plnia len štyri krajiny (Dánsko, Mad’arsko, Portugalsko, Slovensko), a to tak pre jednotlivo podávané zásielky, ako aj pre hromadne podávané zásielky. Po stanovení ciel'ov kvality je ich plnenie monitorované a výsledky sú publikované (okrem Cypru, Estónska a Litvy).[3]

Ďalšou významnou normou, ktorú implementovali niektoré členské krajiny smerom k zvyšovaniu kvalitatívnej úrovne poskytovaných služieb a zlepšovaniu spokojnosti zákazníkov je norma EN 14012 (Poštové služby. Kvalita služby. Princípy vybavovania st’ažností a reklamácií). Táto európska norma špecifikuje požiadavky na meranie st'ažností a postupy náhradového konania, ktoré sa týkajú vnútroštátnej i medzinárodnej poštovej služby.

\subsection{Sledovanie a hodnotenie kvality v zahraničí - Česká pošta, s. p.}

Dohl'ad nad dodržiavaním základných kvalitatívnych požiadaviek stanovených pre univerzálnu poštovú službu je v kompetencii Českého telekomunikačného úradu. Z dostupných zdrojov je zrejmé, že meranie kvality poštových služieb v Českej pošte, s. p. je zamerané predovšetkým na monitorovanie rýchlosti dodania zásielok a to zmysle normy EN 13850. Rýchlost' dodania je zist'ovaná na vzorke 30000 skúšobných zásielok ročne. [8]

V prvej polovici roku 2011 začala Česká pošta, s. p. využívat' Systém GS1. Stalo sa tak po opakovanom vyhodnotení interných štatistík, z ktorých jednoznačne vyplýval sústavný nárast množstva a sortimentu predávaného tovaru na priehradkách. Organizácia GS1 disponuje štyrmi základnými integrovanými štandardmi určenými pre presnú identifikáciu produktov, zariadení, služieb a obchodných partnerov, tiež pre zodpovedajúcu komunikáciu medzi nimi. Patria tu čiarové kódy, RFID, elektronická výmena dát a globálna dátová synchronizácia. [7] V súčasnosti Česká pošta v spolupráci s Poštovou tlačiarňou cenín začala 
väčšinu svojich novo pripravovaných vydaní poštových známok značit' symbolmi EAN-13. Vo vel'mi krátkej dobe sa podarilo úspešne zaviest' unikátnu štandardnú identifikáciu na báze technológie čiarových kódov. Vysoká kvalita symbolov je zárukou, že všetky operácie využívajúce snímanie čiarových kódov budú rýchle, presné a bezchybné.

Dalším systémom monitorovania kvality je systém vyplývajúci z už spomínanej normy EN 14012. Vd'aka sledovaniu počtu podaných st’ažností/reklamácií je možné objavovat' miesta, ktoré je potrebné pre zvýšenie kvality poskytovaných služieb napravit'. $\mathrm{Z}$ dostupných zdrojov vyplýva, že na 1 milión podaných poštových zásielok a poštových poukazov spadajúcich do univerzálnej služby v roku 2011 pripadlo 174 uplatnených st’ažností/reklamácií, pričom z tohto počtu bolo 87 st’ažností/reklamácií uznaných ako opodstatnených. $\mathrm{V}$ prípade poškodenia a úbytku obsahu na 1 milión podaných poštových zásielok pripadlo 66 st’ažností/reklamácií z čoho bolo 47 st’ažností/reklamácií uznaných ako opodstatnených. Vývoj v oblasti st’ažností/reklamácií za posledné tri dostupné roky t.j. 2009 2011 je znázornený v Tabul'ke 1. [7]

Tabul'ka 1. Prehl'ad vývoja st’ažností/reklamácií na Českej pošte, š.p.

\begin{tabular}{|c|c|c|c|}
\hline \multirow{2}{*}{ Prehl'ad st’ažností/reklamácií zákazníkov (Ks) } & \multicolumn{3}{|c|}{ Obdobie } \\
\hline & 2009 & 2010 & 2011 \\
\hline Podaj, preprava, dodaj zásielok & 725181000 & 700779000 & 630209000 \\
\hline $\begin{array}{l}\text { Vybavené st’ažnosti/reklamácie na dodanie poštovej zásielky } \\
\text { (okrem reklamácií na doručenky) }\end{array}$ & 72563 & 76165 & 76191 \\
\hline Z toho opodstatnených & 10352 & 12653 & 15117 \\
\hline Vybavené st’ažnosti/reklamácie poštových služieb s doručenkou & 42719 & 39876 & 39292 \\
\hline $\begin{array}{l}\text { Vybavené st’ažnosti/reklamácie na poškodenie alebo úbytok } \\
\text { obsahu zásielok }\end{array}$ & 6980 & 6919 & 6543 \\
\hline Z toho opodstatnených & 5542 & 5224 & 4933 \\
\hline Iné st’ažnosti/reklamácie & 8016 & 7636 & 7079 \\
\hline Z toho opodstatnených & 2154 & 1269 & 1375 \\
\hline Spolu podané st’ažnosti/reklamácie & 130278 & 130596 & 129105 \\
\hline Z toho opodstatnených & 18048 & 19146 & 21425 \\
\hline
\end{tabular}

Zdroj: vlastné spracovanie podl'a [7] [8]

Z uvedenej Tabul'ky 1. je zrejmé, že počet podaných a dodaných zásielok, každým rokom klesá. Medzi najčastejšie dôvody podania st’ažností/reklamácií patrila strata a zdíhavé (oneskorené) dodávanie zásielok, poškodenie alebo úbytky zásielok a $\mathrm{v}$ neposlednom rade neprofesionálny prístup samotných zamestnancov.

\subsection{Sledovanie a hodnotenie kvality na Slovensku}

Systém riešenia kvality poštových služieb poskytovaných v rámci univerzálnej služby (US) je zakotvený v Zákone č. 324/2011 Z. z. o poštových službách riešený nástrojmi, ktoré sú súčast'ou Poštovej licencie, a to v jej prílohe „Požiadavky na kvalitu univerzálnej poštovej služby“. Dôležitým nástrojom na integráciu v rámci európskeho trhu poštových služieb a na zvyšovanie kvality univerzálnej služby slúži technická normalizácia. Tak ako bolo uvedené vyššie aj pre SR platí povinnost' zabezpečovat' meranie a vyhodnocovanie dosiahnutej úrovne kvality v kategórií univerzálnej služby v zmysle platných noriem.

Dohl'ad nad dodržiavaním základných kvalitatívnych požiadaviek stanovených pre univerzálnu službu vykonáva Poštový regulačný úrad (PRÚ). Ide predovšetkým o parametre súvisiace s pravidelnostou, spol'ahlivost’ou, dostupnostou univerzálnej služby, ale tiež s lehotou dodania zásielok.

Poskytovatel' univerzálnej služby je povinný každoročne zasielat' PRÚ správu o výsledkoch prešetrovania st'ažností/reklamácií najneskôr do 10 dní odo dňa zverejnenia. Táto správa $\mathrm{v}$ sebe zahŕňa prehl'ad o počte st’ažností/reklamácií, ktoré sa týkajú dodržiavania povinností podl'a zákona o poštových službách a týchto požiadaviek, ktoré boli v priebehu uplynulého kalendárneho roka podané u poskytovatel'a US vrátane spôsobu, akým boli 
vybavené (opodstatnené alebo neopodstatnené st’ažnosti/reklamácie, vyčíslenie a prehl'ad dôvodov st’ažností/reklamácií). [4]

\section{Vykazovanie st’ažností/reklamácií}

Správy o st’ažnostiach/reklamáciách môžu uvádzat' široký rozsah informácií. Je však nutné podotknút, že všetky poštové organizácie vrátane Slovenskej pošty, a.s. (SP, a.s.) ako poskytovatel'a US musia vo svojej správe uviest' základné informačné položky, medzi ktoré patrí: [8]

a) počet všetkých podaných st’ažností/reklamácií podl'a základného druhu (príčiny st'ažností/reklamácií),

b) počet st’ažností/reklamácií, ktorých výsledkom je vyplatenie náhrady.

SP, a.s. je povinná predložit' informácie minimálne o šiestich najčastejších typoch st’ažností/reklamácií podl'a množstva prijatých st’ažností/reklamácií.

Tabul'ka 2. Počet podaných st’ažností/reklamácií - Slovenská pošta, a. s.

\begin{tabular}{|l|r|r|r|}
\hline \multirow{2}{*}{ Prehl'ad podaných st’ažností/reklamácií $(\mathbf{K})$} & \multicolumn{3}{|c|}{ Obdobie } \\
\cline { 2 - 4 } & \multicolumn{1}{|c|}{$\mathbf{2 0 0 9}$} & \multicolumn{1}{|c|}{$\mathbf{2 0 1 0}$} & $\mathbf{2 0 1 1}$ \\
\hline Príjem, preprava a doručenie zásielok & 339183674 & 314668479 & 284666889 \\
\hline Počet podaných st’ažností/reklamácií na poskytované služby & 85281 & 67170 & 60730 \\
\hline Z toho opodstatnených & 7075 & 6194 & 5558 \\
\hline Počet podaných st’ažností/reklamácií na US & 54437 & 53243 & 48851 \\
\hline Z toho opodstatnených & 4986 & 4063 & 3883 \\
\hline Spolu podané st’ažnosti/reklamácie & 139718 & 120413 & 109581 \\
\hline Z toho opodstatnených & $\mathbf{1 2 ~ 0 6 1}$ & $\mathbf{1 0 2 5 7}$ & $\mathbf{9 4 4 1}$ \\
\hline
\end{tabular}

Zdroj: vlastné spracovanie podl'a [6] [9]

Hlavným ciel’om systému vybavovania st'ažností/reklamácií pre SP, a.s. je zabezpečit' trvalé zlepšovanie celkovej kvality poskytovaných služieb a použitie informácií získaných z procesu vybavovania st’ažností/reklamácií na zlepšovanie celkovej kvality poskytovaných služieb, ktorú vníma samotný zákazník.

\section{Ciel' a metodika práce}

Ciel'om príspevku je demonštrovat' možnosti merania a vyhodnocovania st'ažnosti a reklamácií za účelom monitorovania kvalitatívnej úrovne poskytovaných služieb a zabezpečovania spokojnosti zákazníkov.

Kvantita a charakter podaných st’ažností a reklamácií sú pre poskytovatel'a poštových služieb primárnym zdrojom informácií o kvalite/nekvalite samotného poskytovatel'a alebo jeho čiastkových aktivít. $Z$ tohto dôvodu sa uvedený príspevok v diskusnej časti nezaoberá systémami hodnotenia kvalitatívnych ukazovatel'ov dostupnosti a rýchlosti, ktorým je v iných prácach venovaná značná pozornost', ale naopak je výlučne zameraný smerom k st'ažnostiam a reklamáciám, ktoré sú často diskutované aj ako problematika ochrany spotrebitel'a.

SP, a. s. ako poskytovatel' US v zmysle dodržiavania poštových smerníc je povinná raz ročne uverejnit' informáciu o počte st’ažností/reklamácií a o spôsobe ako tieto st'ažnosti a reklamácie boli vybavené.

Príspevok na konkrétnom príklade ukazuje možnost' aplikácie postupov normy STN EN 14012 podl'a odporúčanej metodiky.

\section{Výsledky a diskusia}

Riešenie st’ažností a reklamácií podl'a normy STN EN 14012 je možné využit' pre všetky typy poštových služieb, pre US, ako aj pre neuniverzálnu službu. Normu môžu využívat' všetky typy poštových organizácií ktoré sa týkajú vnútroštátnej i medzinárodnej poštovej služby. Pozornost' sa venuje vybavovaniu st'ažností/reklamácií aj v takom prípade, že poštovú službu vykonávajú viaceré poštové podniky. Norma poskytuje návod aj na náhradové a nápravné postupy. [4] 
Táto európska norma poskytuje pravidlá nad rámec požiadaviek určených v normách ISO 10002 a ISO 9001, s ciel'om posúdit' účinnost' a efektívnost' procesu vybavovania st’ažností/reklamácií a následne potenciál na zlepšenie výkonnosti organizácie. Oproti norme ISO 9001 sú ciele spokojnosti zákazníka a kvality produktu rozšírené a zahŕňajú spokojnost' zainteresovaných strán a taktiež výkonnost' organizácie.

Norma sa zaoberá procesmi organizácie a následne princípmi manažérstva kvality, na základe ktorých sa môže rozšírit' v rámci celej organizácie. Zámerom tejto európskej normy je dosiahnut' trvalé zlepšovanie merané pomocou spokojnosti zákazníkov a ostatných zainteresovaných strán. Je však vhodné poznamenat', že počet prijatých st’ažností/reklamácií nemusí vždy súvisiet' $s$ úrovňou danej služby. Naopak, vel'ké množstvo podaných st'ažností/reklamácií môže odrážat' účinnost' procesu vybavovania st’ažností/reklamácií poštového podniku. [4]

\subsection{Proces vybavovania st’ažností/reklamácií}

Proces vybavovania st'ažností/reklamácií má byt' l'ahko prístupný všetkým st'ažovatel'om prostredníctvom rôznych prístupových kanálov (telefonicky, písomne, emailom, osobne, ...) tak, aby žiaden st’ažovatel' nemohol byt' znevýhodnený. K dispozícii musia byt' všetky dostupné informácie o podrobnostiach podávania a riešenia st’ažností/reklamácií. [4]

St’ažnosti/reklamácie môžu byt' prijaté od odosielatel'a alebo adresáta poštovej zásielky, ale aj od iného používatel'a poštovej služby.

St'ažnost'/reklamáciu podáva st'ažovatel' prostredníctvom štandardizovaného Reklamačného listu, ktorý musí byt' dostupný v rámci každej poštovej prevádzky, na internetovej stránke pošty alebo ho možno na požiadanie získat' elektronicky/faxom zo Zákazníckeho servisu SP, a.s.

V prípade, že sa st'ažnost'/reklamácia nemôže vybavit' okamžite, je potrebné potvrdit' st'ažovatel'ovi príjem st'ažnosti/reklamácie. St’ažovatelia musia byt' na požiadanie informovaní o stave ich st’ažnosti/reklamácie v rámci procesu vybavovania st’ažností/reklamácií vrátane informácie, kedy sa predpokladá nasledujúci krok alebo konečná odpoved' na ich st’ažnost'/reklamáciu.

\subsection{Zhromažd'ovanie informácií o st’ažnostiach/reklamáciách}

Informácie, ktoré sa majú zaznamenávat', musia byt' dostatočné na to, aby poskytovatel' poštovej služby mohol efektívne vybavovat' st'ažnosti/reklamácie. Pri prijímaní st’ažností/reklamácií, je potrebné zhromaždit' také podrobnosti o st’ažnosti/reklamácii ako je [4] meno a adresu osoby, ktorá sa st'ažuje, dátum podania, príčinu st'ažnosti/reklamácie (druh/kategóriu st’ažnosti/reklamácie), produkt, službu alebo súvisiace organizačné postupy týkajúce sa st’ažnosti/reklamácie, podporný opis st’ažnosti/reklamácie ak sa vyžaduje, a relevantné podporné údaje, kto zaregistroval st’ažnost'/reklamáciu a kde v poštovej organizácii pracuje, či sa st'ažnost'/reklamácia podala v určenej lehote, a pod.

Na meranie st'ažností/reklamácií musí poskytovatel' služby zaznamenávat' minimálne samostatné údaje pre každú kategóriu st’ažností/reklamácií uvedenú v Tabul'ke 3.

Tabul'ka 3. Kategórie st’ažností/reklamácií

\begin{tabular}{|l|l|}
\hline • Stratená alebo podstatne oneskorene dodaná zásielka & $\bullet$ Nesprávne dodanie \\
\hline • Oneskorene dodaná zásielka & $\bullet$ Prístup k informáciám o službách zákazníkom \\
\hline - Poškodená zásielka & $\bullet$ Správanie a odbornost' poštových zamestnancov \\
\hline • Zmena adresy & $\bullet$ Dostupnost' poštových služieb \\
\hline • Dodávanie alebo vyberanie poštových zásielok & $\bullet$ Vybavovanie st'ažností/ reklamácií \\
\hline - Iné st’ažnosti/ reklamácie (nevhodné na zaradenie do predchádzajúcich kategórií) \\
\hline
\end{tabular}

Zdroj: autor 
Poštový podnik je taktiež povinný určit' maximálny čas (lehotu), v ktorom sa musí st’ažnost'/reklamáciu vyriešit'. Maximálny čas musí byt':

- nie viac ako 30 kalendárnych dní pre vnútroštátnu US,

- nie viac ako 40 kalendárnych dní pre cezhraničnú US v rámci priemyselných krajín,

- nie viac ako 60 kalendárnych dní pre cezhraničnú US do ostatných krajín.

\subsection{Meranie st’ažností/reklamácií - Záznamy a štatistické ukazovatele}

Na meranie st’ažností/reklamácií a náhradového konania musí SP, a.s. zaznamenat' aspoň samostatné údaje pre každú kategóriu st’ažností/reklamácií, pričom systém merania musí byt' $v$ činnosti počas celého roka.

Ak je st’ažnost'/reklamácia prijatá na niekol'ko jednotlivých poštových zásielok, každá zásielka musí byt' považovaná za samostatnú st'ažnost'/reklamáciu a musí sa kategorizovat' osobitne. V prípade, že sa prijímajú st’ažnosti/reklamácie, ktoré sa týkajú tej istej individuálnej zásielky od niekol'kých používatel'ov, je možné ich považovat' za jednotlivú st’ažnost'/reklamáciu.

Systém manažérstva st’ažností/reklamácií by mal SP, a.s. poskytnút' minimálne ukazovatele o st'ažnostiach/reklamáciách ako celku a aspoň pre kategóriu st'ažností/ reklamácií, ktoré sa tykajú straty, poškodenia a oneskorenia v US. Rovnaké ukazovatele sa môžu poskytnút' aj pre d’alšie kategórie st’ažností/reklamácií. [4]

Tabul'ka 4 Ukazovatele merania st’ažností a reklamácií

Sledované ukazovatele merania st’ažností a reklamácií

- Nc - počet st’ažností/reklamácií podaných vo vykazovacom období,

- Ac - počet st’ažností/reklamácií podaných vo vykazovacom období, ktoré sa posúdili ako opodstatnené,

- Rc - počet st’ažností/reklamácií podaných vo vykazovacom období, pri ktorých sa vyplatila náhrada,

- Ht - percentuálny podiel st’ažností/reklamácií podaných vo vykazovacom období, kde sa konečná odpoved' poslala $\mathrm{v}$ určenej lehote

- Tc1 - priemerný čas na oznámenie prvej odpovede st’ažovatel'ovi na st’ažnosti/reklamácie podané vo vykazovacom období,

- Tc2 - priemerný čas na odoslanie konečnej odpovede st’ažovatel'ovi na st’ažnosti/reklamácie podané vo vykazovacom období,

- Tc3 - priemerný čas na zaslanie náhrady st’ažovatel’ovi pri st’ažnostiach/reklamáciách podaných vo vykazovacom období vypočítaný od dátumu prijatia st’ažnosti/reklamácie,

- Tc4 - priemerný čas na zaslanie náhrady st’ažovatel’ovi pri st’ažnostiach/reklamáciách podaných vo vykazovacom období vypočítaný od dátumu poslania konečnej odpovede st’ažovatel'ovi.

Tc1, Tc2, Tc3 a Tc4 sú vypočítané ako počet kalendárnych dní medzi dňom, ked' sa st’ažnost'/reklamácia prijala, a dňom, ked' sa odoslala odpoved'.

Ukazovatel' Ht je vyjadrený ako percentuálny podiel Nc všetkých st’ažností/reklamácií podaných vo vykazovacom období.

Ukazovatele Tc1 a Tc2 sú vyjadrené ako priemery všetkých st’ažností/reklamácií podaných vo vykazovacom období.

Ukazovatele Tc3 a Tc4 sú vyjadrené ako priemery všetkých st’ažností/reklamácií podaných vo vykazovacom období, kde sa vykonali platby náhrad

\begin{tabular}{|l|l|} 
Inc $=\frac{N G}{M} 100$ & $\begin{array}{l}\text { Inc }- \text { počet st’ažností/reklamácií ako percentuálny podiel skutočného objemu poštových } \\
\text { zásielok }\end{array}$ \\
\hline Iac $=\frac{A C}{M} 100$ & $\begin{array}{l}\text { Iac }- \text { počet opodstatnených stažností/reklamácií ako percentuálny podiel skutočného objemu } \\
\text { poštových zásielok }\end{array}$ \\
\hline $\boldsymbol{I r c}=\frac{K C}{M} 100$ & Irc - počet platieb náhrad ako percentuálny podiel skutočného objemu poštových zásielok \\
\hline $\mathbf{M}=$ objem skutočných poštových zásielok
\end{tabular}

Zdroj: vlastné spracovanie podl'a [4]

Pre st’ažnosti/reklamácie, ktoré sa týkajú stratených, oneskorených alebo poškodených zásielok, musí každá správa pre každú kategóriu obsahovat' počet prijatých st’ažností/reklamácií vyjadrených ako percentuálny podiel zodpovedajúci objemu poštových zásielok spracovaných prevádzkovatel’om poštovej služby. 
Každá správa, ktorá je predkladaná PRÚ musí obsahovat' minimálne výsledky ukazovatel'ov, ktoré merajú st’ažnosti/reklamácie ako celok a osobitne každú kategóriu st’ažností/reklamácií týkajúcich sa straty, poškodenia a oneskorenia. Pre každú vykazovanú kategóriu st’ažností/reklamácií musí každá správa obsahovat' všetky ukazovatele Nc, Ac, Rc, Ht, Tc1, Tc2, Tc3 a Tc4. Pre st’ažnosti/reklamácie týkajúce sa vnútroštátnej aj cezhraničnej US sa musia uvádzat' samostatné údaje. Samostatné údaje sa uvádzajú pre st’ažnosti/reklamácie súvisiace s cezhraničnými listovými a balíkovými zásielkami, ktoré sa podali alebo dodali v rámci EÚ alebo nejakej inej definovanej skupine krajín, pričom by sa mali uviest' aj názvy krajín patriacich do tejto skupiny. [4]

\section{4 Štúdia: Meranie kvality prostredníctvom st’ažností a reklamácií pre produkt balíky}

St’ǎnosti/reklamácie podané zákazníkmi sú jednou z najlacnejších foriem získavania informácií o spokojnosti a kvalite poskytovaných služieb, tak ako ich vnímajú samotní zákazníci. Účelom merania podaných st’ažností/reklamácií na balíkové zásielky je:

- snaha odhalit' a identifikovat' slabé miesta pri poskytovaní týchto služieb,

- navrhnút' možné nápravné opatrenia na zlepšenie poskytovaných služieb,

- odstránenie zistených nedostatkov v rámci poskytovaných služieb,

- zvýšit' konkurencieschopnost' SP, a.s. na balíkovom trhu,

- zvýšit' výnosy SP, a.s., kvalitne poskytovanými službami,

- zvyšovat' spokojnost' zákazníkov s poskytovanými službami a eliminovat' ich nespokojnost',

Pri evidovaní st’ažností/reklamácií využíva SP, a.s. Informačný systém (IS) určený predovšetkým na automatizáciu priehradkových operácií vykonávaných na všetkých pobočkách SP, a.s. Vd'aka centrálnemu IS je možné prepojit' celú poštovú siet' pomocou jedného servera. IS priehradkových operácií sa využíva predovšetkým pre spracovania podaja a dodaja všetkých druhov zásielok, peňažných operácií, výplat dôchodkov a sociálnych dávok, služby Poštovej banky, a.s., predaj tovarov a pod. Výstupy z IS sú následne spracovávané v nadväzujúcich informačných systémoch. Jedným z nich je aj IS pre spracovanie st’ažností a reklamácií a iné, ktoré využíva SP, a.s. pre svoje účely.

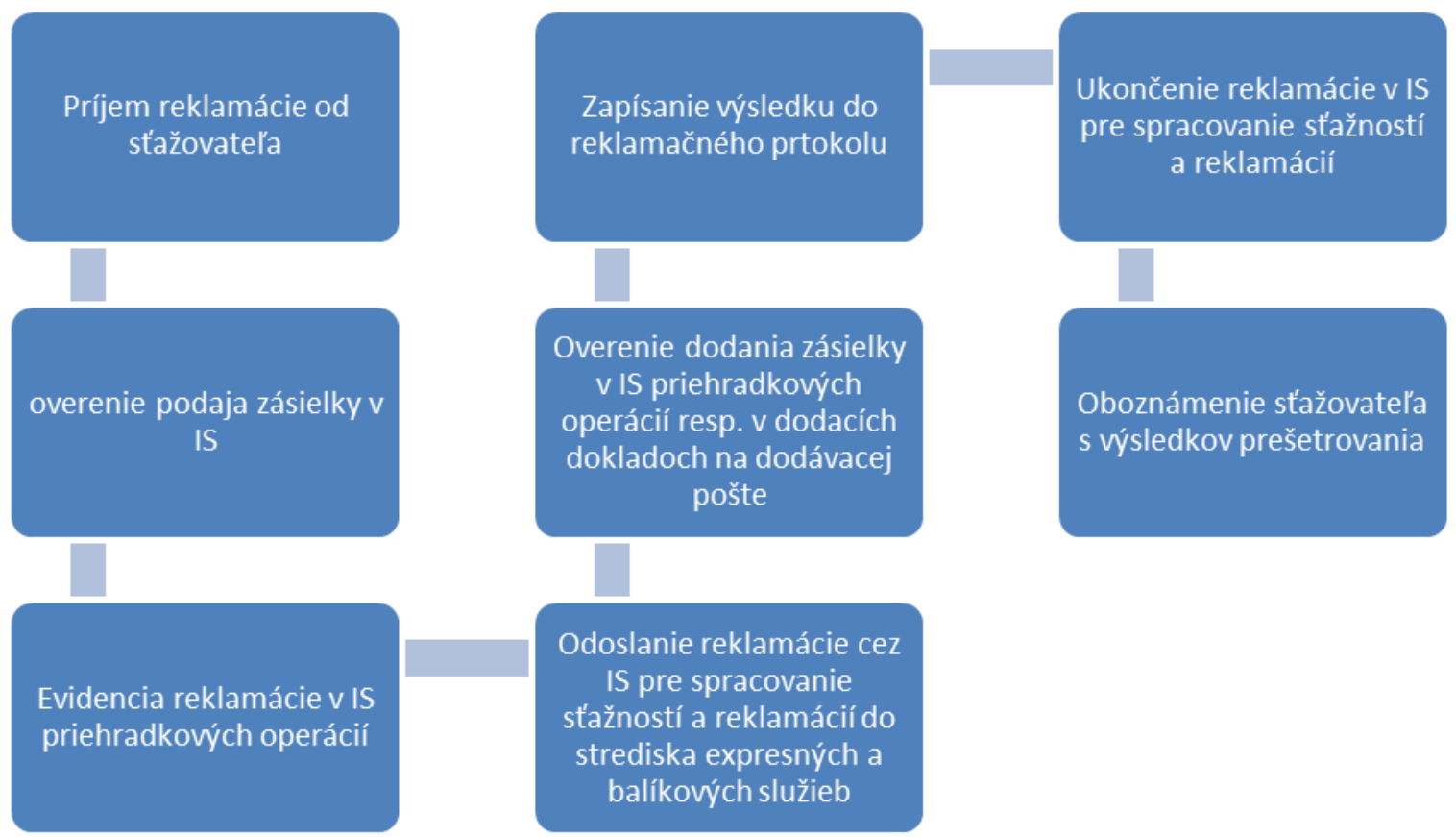

Obrázok 1. Spracovanie prijatej st’ažnosti/reklamácie (Zdroj: Autor) 


\subsection{1 Štatistické údaje - pobočky: Pošta A a Pošta B}

Pre účely príspevku boli štatistické údaje zozbierané za obdobie 6 mesiacov z dvoch vybraných poštových prevádzok v Žilinskom kraji. V nasledovných Tabul'kách 5., 6. je uvedený počet všetkých podaných a dodaných balíkov I. a II. triedy a počet podaných st’ažností/reklamácií na balíky I. a II. triedy za jednotlivé mesiace. Sledovanie zahŕňa podaj a dodaj zásielok vo vnútroštátnom styku (VS) aj v medzinárodnom styku (MS) Z dôvodu, že zákazníci podávali len reklamácie na balíkové služby budeme používat' už len pojem reklamácie.

Tabul'ka 5. Podané reklamácie - pošta $\mathrm{A}$

\begin{tabular}{|c|c|c|c|c|c|c|c|c|}
\hline \multirow[b]{2}{*}{ Obdobie } & \multicolumn{4}{|c|}{ Podaj (Ks) } & \multicolumn{2}{|c|}{ Dodaj (Ks) } & \multicolumn{2}{|c|}{ Podané reklamácie (Ks) } \\
\hline & $\begin{array}{l}\text { Balík } \\
\text { I. a II. tr. } \\
\text { VS }\end{array}$ & $\begin{array}{c}\begin{array}{c}\text { Poistený } \\
\text { balík }\end{array} \\
\text { I. a II. tr. } \\
\text { VS }\end{array}$ & $\begin{array}{l}\text { Balíky } \\
\text { I. a II. tr. } \\
\text { MS }\end{array}$ & $\begin{array}{c}\begin{array}{c}\text { Poistený } \\
\text { balík }\end{array} \\
\text { I. a II. tr. } \\
\text { MS }\end{array}$ & $\begin{array}{l}\text { Balík a } \\
\text { Poistený } \\
\text { balík } \\
\text { I. a II. tr. } \\
\quad \text { VS }\end{array}$ & $\begin{array}{l}\text { Balíky a } \\
\text { Poistený } \\
\text { balík } \\
\text { I. a II. tr. } \\
\quad \text { MS }\end{array}$ & $\begin{array}{l}\text { Opodstat- } \\
\text { nené }\end{array}$ & $\begin{array}{l}\text { Neopod- } \\
\text { statnené }\end{array}$ \\
\hline $\begin{array}{l}\text { September } \\
2012\end{array}$ & 1194 & 471 & 101 & 23 & 2908 & 50 & 7 & 11 \\
\hline Október 2012 & 1362 & 647 & 166 & 32 & 3434 & 120 & 7 & 16 \\
\hline $\begin{array}{l}\text { November } \\
2012\end{array}$ & 2067 & 590 & 148 & 45 & 3621 & 75 & 5 & 19 \\
\hline $\begin{array}{l}\text { December } \\
2012\end{array}$ & 1895 & 638 & 233 & 38 & 3661 & 230 & 14 & 29 \\
\hline Január 2013 & 1799 & 435 & 82 & 94 & 4246 & 80 & 8 & 23 \\
\hline Február 2013 & 1647 & 385 & 81 & 71 & 4366 & 40 & 6 & 11 \\
\hline \multirow{3}{*}{\multicolumn{4}{|c|}{ Zdroj: vlastné spracovanie podl'a [10] }} & \multicolumn{3}{|c|}{ Celkom podaj+dodaj VS } & \multicolumn{2}{|r|}{35366} \\
\hline & & & & \multirow{2}{*}{\multicolumn{3}{|c|}{$\begin{array}{l}\text { Celkom podaj+dodaj MS } \\
\text { Celkom podané reklamácie }\end{array}$}} & & 1709 \\
\hline & & & & & & & & 156 \\
\hline
\end{tabular}

Ďalšou sledovanou prevádzkarňou je Pošta $\mathrm{B}$, kde boli sledované podané reklamácie na balíky I. a II. Triedy rovnako počas obdobia 6 mesiacov.

Tabul'ka 6. Podané reklamácie - Pošta B

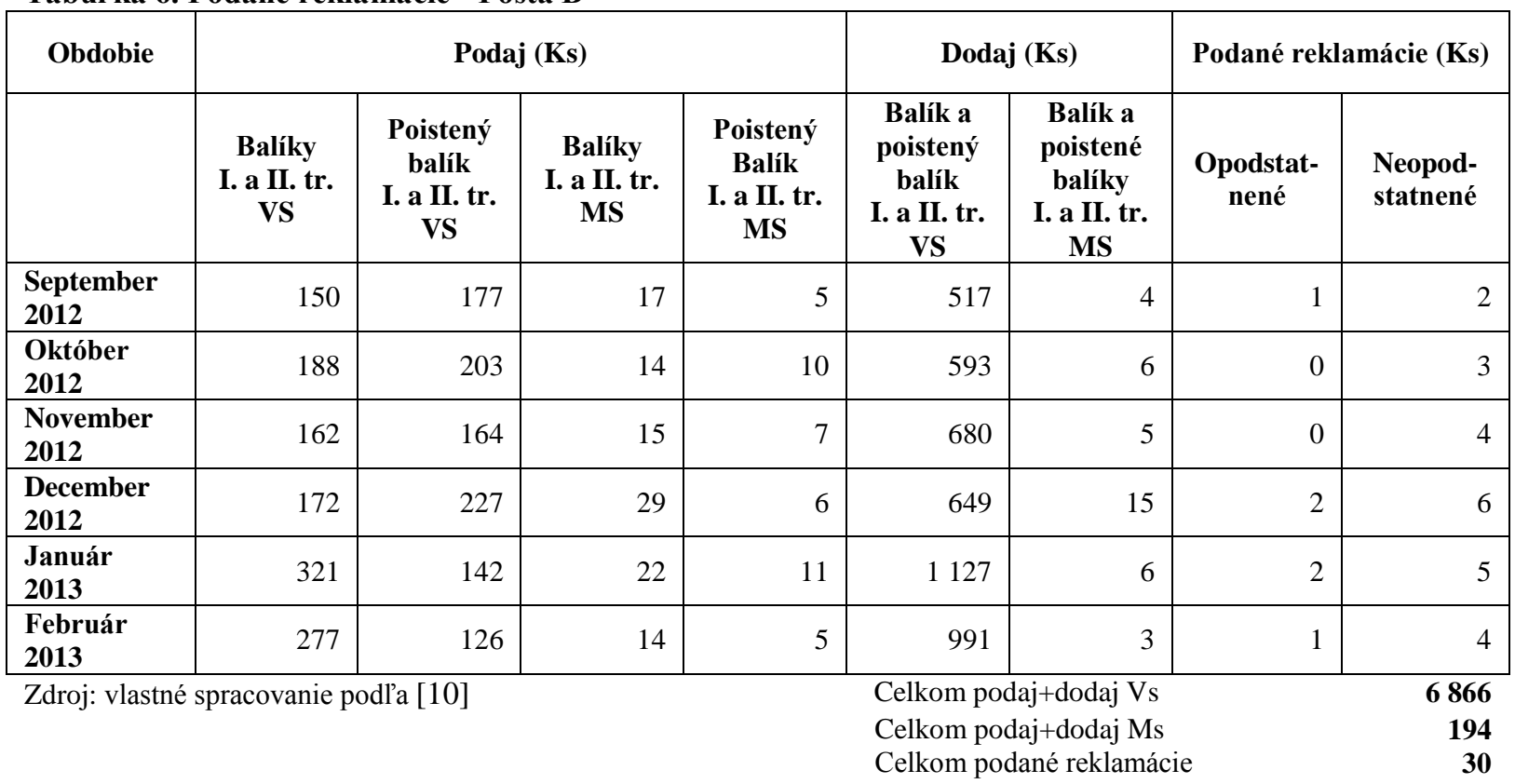

\subsubsection{Primárny výskum}

Údaje pre účely skúmania boli zistené z IS a dohl'adávania v reklamačných protokoloch. Následne boli údaje spracovávané $v$ tabul'kách a na základe metodiky stanovenej v STN EN 14012 boli uskutočnené výpočty za sledované obdobie. 


\section{Zber údajov Pošta A}

Všetky potrebné štatistické údaje sú spracované v tabul'ke pod názvom Podané reklamácie na vnútroštátne balíky I. a II. triedy Pošta A, za celé sledované obdobie 6 mesiacov. Tabul'ka 7 obsahuje počet podaných a dodaných balíkov I. a II. triedy VS, ale predovšetkým počet podaných reklamácií na balíky I. a II. triedy VS rozdelený na konkrétne kategórie dôvodov podaných reklamácií.

Tabul'ka 7. Podané reklamácie na vnútroštátne balíky I. a II. triedy - Pošta A

\begin{tabular}{|l|r|r|r|r|r|r|r|}
\hline & M (Ks) & Nc (Ks) & Inc (\%) & Ac (Ks) & Iac (\%) & Rc (Ks) & Irc (\%) \\
\hline $\begin{array}{l}\text { Počet vnútroštátnych } \\
\text { balíkov }\end{array}$ & 35366 & - & - & - & - & - & - \\
\hline $\begin{array}{l}\text { Stratená alebo podstatne } \\
\text { oneskorene dodaná } \\
\text { zásielka }\end{array}$ & - & 12 & 0,033931 & 7 & 0,019793 & 7 & 0,019793 \\
\hline Poškodená zásielka & - & 34 & 0,096137 & 10 & 0,028275 & 5 & 0,014137 \\
\hline $\begin{array}{l}\text { Nevyplatenie dobierkovej } \\
\text { sumy }\end{array}$ & - & 80 & 0,226206 & 23 & 0,06503 & 23 & 0,065034 \\
\hline Iné & - & 25 & 0,070689 & 7 & 0,019793 & & 0,002827 \\
\hline
\end{tabular}

Zdroj: vlastné spracovanie podl'a [10]

Z celkového počtu 151 podaných reklamácií na balíky I. a II. triedy VS bolo vyhodnotených 104 reklamácií ako neopodstatnených, čo predstavuje za celé sledované obdobie $68,88 \%$. Pri 47 podaných reklamáciách bolo uznané, že tieto reklamácie boli podané opodstatnene, čo predstavuje $31,12 \%$.

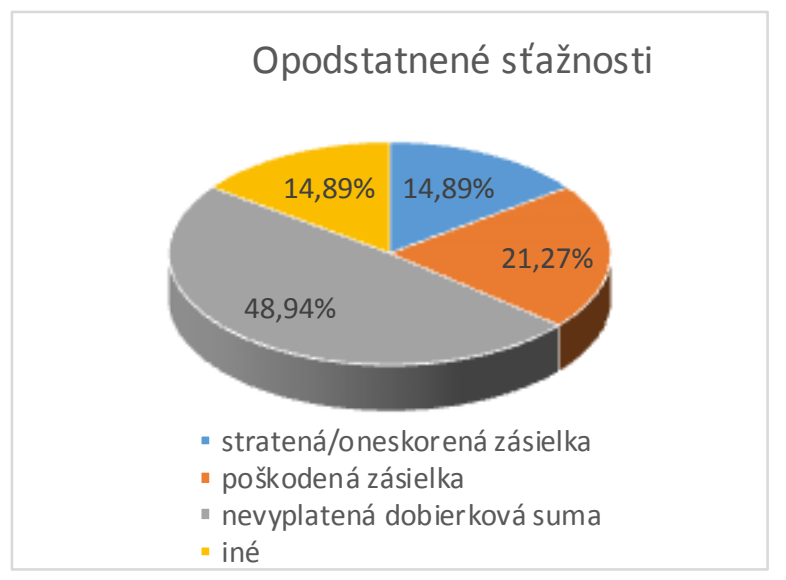

Obrázok 2 Opodstatnené st’ažnosti podl'a druhu

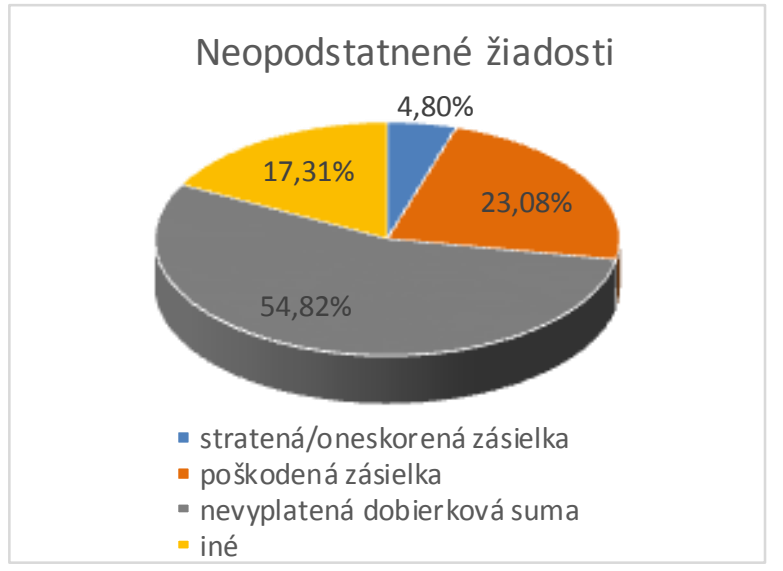

Obrázok 3 Neopodstatnené st'ažnosti podl'a druhu

(Zdroj: Autor)

Z celkového počtu opodstatnených reklamácií, ktorých počet predstavoval 47 uznaných reklamácií bolo v náhradovom konaní vyplatených 36 reklamácií čo predstavuje 76,60 \% za celé sledované obdobie. Z Obrázku 4 je zrejmé, že najväčší počet vyplatených náhrad pripadlo na kategóriu „Nevyplatená dobierková suma“, kde až ku 23 reklamáciám bola vyplatená náhrada čo predstavuje viac ako 63 \% zo všetkých reklamácií, ku ktorým bola vyplatená náhrada. K d’alším kategóriám reklamácií, ku ktorým boli vyplatené náhrady patria s počtom 7 reklamácií „Stratená/oneskorená zásielka“ a s počtom 5 vyplatených náhrad „Poškodená zásielka“. V kategórii „Iné“ bola vyplatená náhrada k zásielke, ktorá bola nesprávne doposielaná 


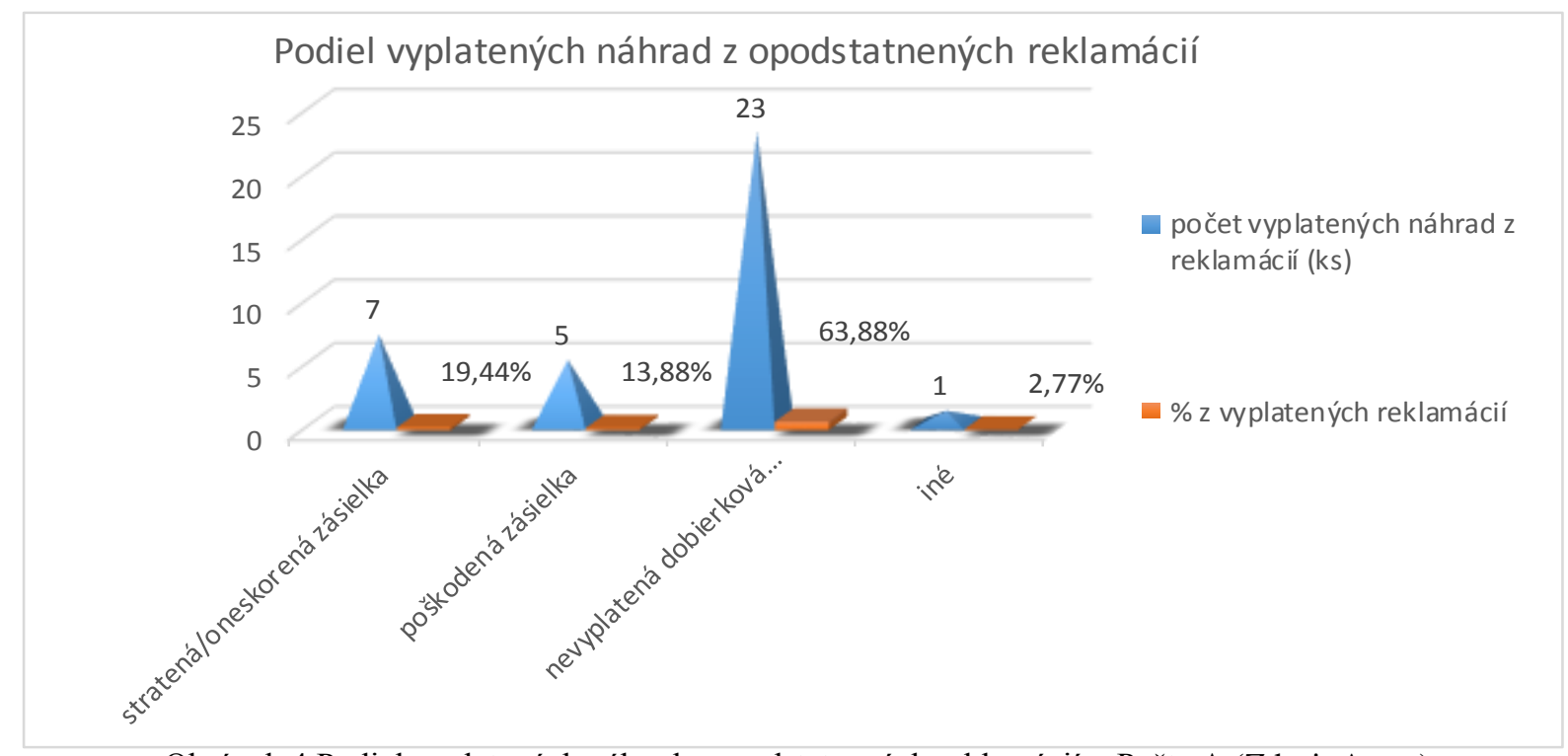

Obrázok 4 Podiel vyplatených náhrad z opodstatnených reklamácií - Pošta A (Zdroj: Autor)

\section{Zber údajov Pošta B}

Tak ako pri predchádzajúcom prípade, všetky potrebné štatistické údaje sú spracované v prehl'adnej tabul'ke pod názvom Podané reklamácie na vnútroštátne balíky I. a II. triedy Pošta B, za sledované obdobie 6 mesiacov. Tabul'ka 8 obsahuje počet podaných a dodaných balíkov I. a II. triedy VS, ale najmä počet podaných reklamácií na balíky I. a II. triedy rozdelený podl'a sledovaných kategórií reklamácií.

Tabul'ka 8 Podané reklamácie na vnútroštátne balíky I. a II. triedy - Pošta B

\begin{tabular}{|l|l|l|l|l|l|l|l|}
\hline & $\mathbf{M}(\mathbf{K s})$ & $\mathbf{N c}(\mathbf{K s})$ & Inc (\%) & Ac (Ks) & Iac (\%) & Rc (Ks) & Irc (\%) \\
\hline Počet vnútroštátnych balíkov & 6866 & - & - & - & - & - & - \\
\hline $\begin{array}{l}\text { Stratená alebo podstatne } \\
\text { oneskorene dodaná zásielka }\end{array}$ & - & 3 & 0,043693 & 0 & 0 & 0 & 0 \\
\hline $\begin{array}{l}\text { Poškodená zásielka } \\
\text { Nevyplatenie dobierkovej } \\
\text { sumy }\end{array}$ & - & 4 & 0,058258 & 1 & $\begin{array}{l}0,01456 \\
4\end{array}$ & 1 & 0,014564 \\
\hline Iné & - & 20 & 0,291290 & 5 & $\begin{array}{l}0,07282 \\
2\end{array}$ & 5 & 0,072822 \\
\hline
\end{tabular}

Zdroj: vlastné spracovanie podl'a [10]

Z celkového počtu 30 reklamácií podaných na balíky I. a II. triedy bolo len 6 reklamácií uznaných ako opodstatnené. Opodstatnené reklamácie boli uznané len pri dvoch kategóriách.

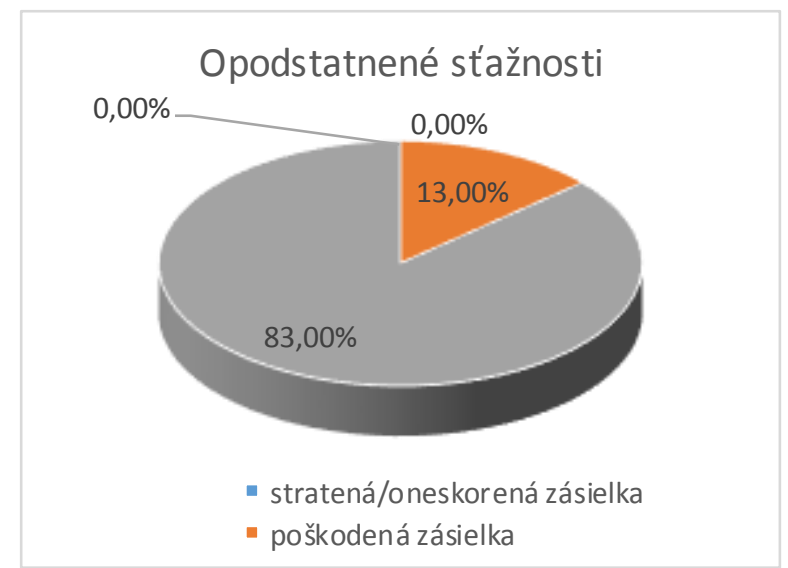

Obrázok 5 Opodstatnené st’ažnosti podl'a druhu

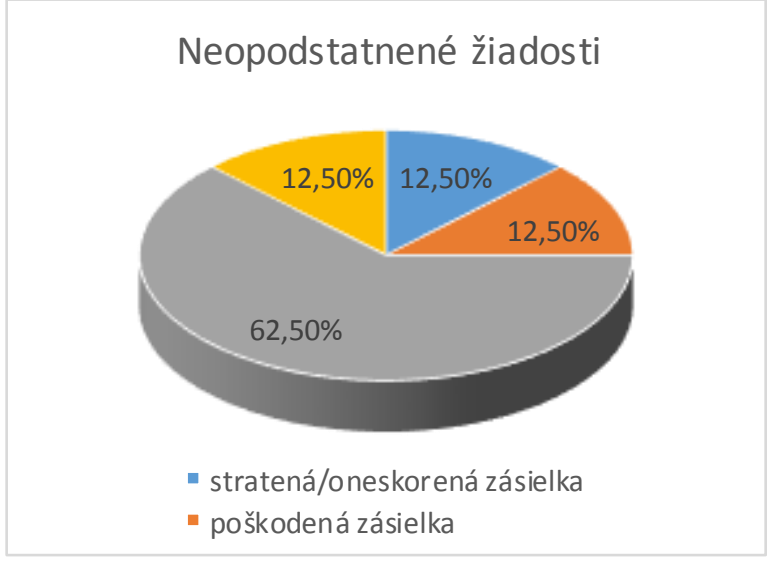

Obrázok 6 Neopodstatnené st’ažnosti podl'a druhu (Zdroj: Autor) 
Z celkového počtu 6 reklamácií, ktoré boli uznané ako opodstatnené bola v náhradovom konaní vyplatená náhrada ku všetkým 6 reklamáciám. Z Obrázku 7. je zrejmé, že najväčší počet vyplatených náhrad pripadlo na kategóriu „Nevyplatená dobierková suma“, kde ku všetkým 5 reklamáciám bola vyplatená náhrada čo predstavuje viac ako $83 \%$. Druhou kategóriu reklamácií kde bola vyplatená 1 náhrada patrí „Poškodená zásielka“ čo predstavuje viac ako $16 \%$. V zvyšných dvoch kategóriách „Stratená/oneskorená zásielka“ a „Iné“ nebola žiadna reklamácia uznaná ako opodstatnená preto nebolo potrebné vyplatit’ žiadnu náhradu.

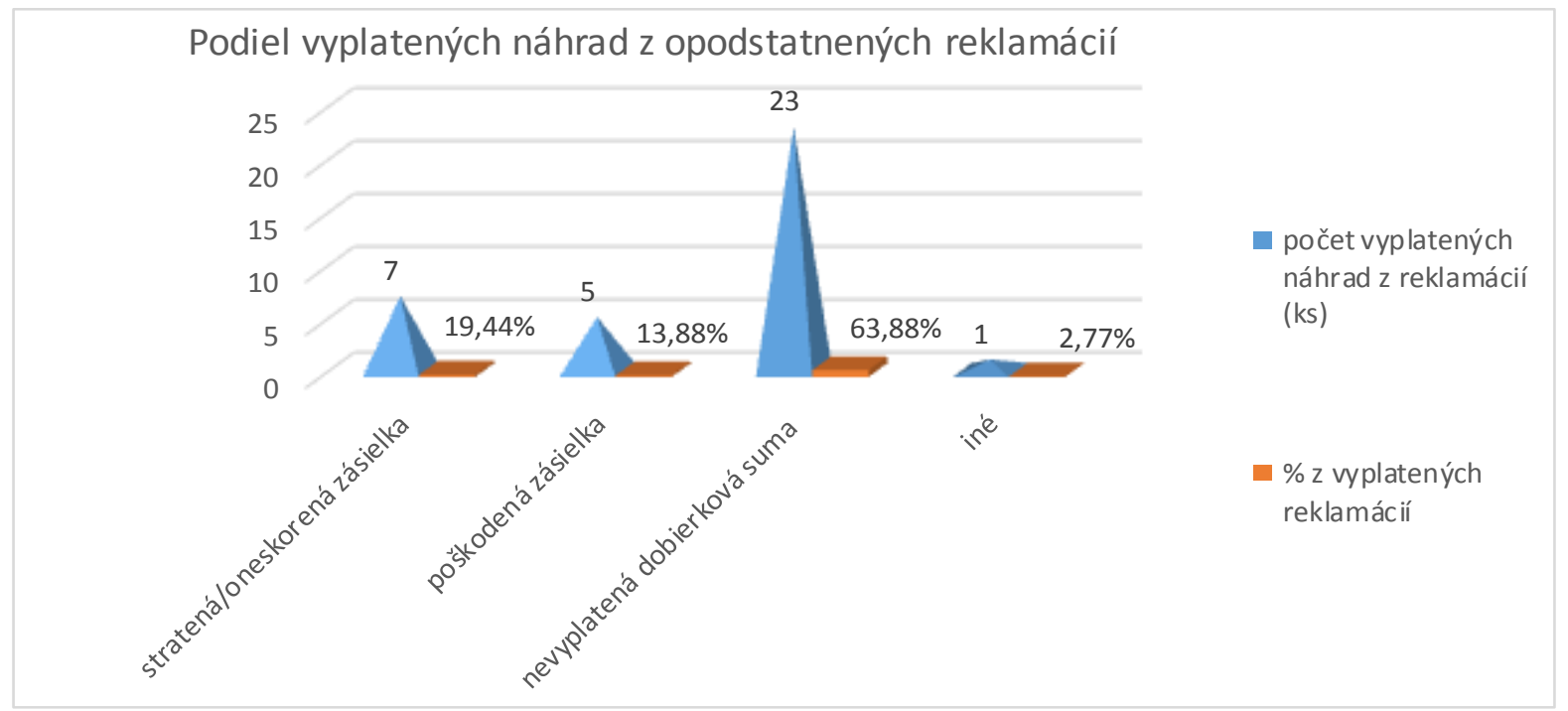

Obrázok 7 Podiel vyplatených náhrad z opodstatnených reklamácií - Pošta B (Zdroj: Autor)

\subsubsection{Vyhodnotenie kvality podaných reklamácií na vnútroštátne balíky}

Z vykonaného primárneho výskumu na zvolených pobočkách pošty je možné konštatovat', že počet podaných reklamácií uznaných ako neopodstatnene podaných je na oboch pobočkách vyšší než počet reklamácií, ktoré boli uznané ako opodstatnené. Počty podaných reklamácií na balíky I. a II. triedy vnútroštátneho styku súvisia aj s vel'kost'ou jednotlivých pobočiek a počtom podaných a dodaných balíkov.

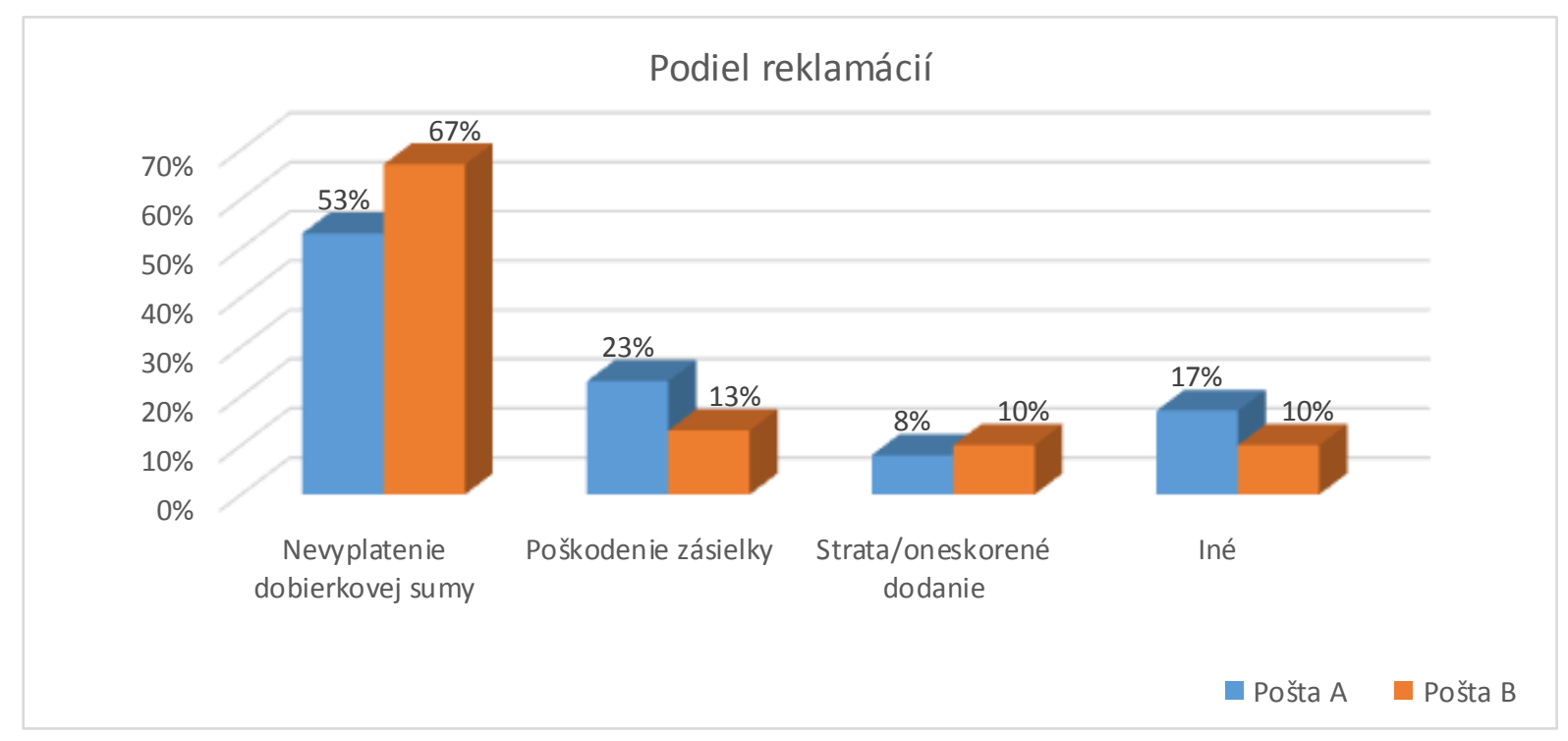

Obrázok 8 Meranie počtu podaných reklamácií (Zdroj: Autor)

Problematickým faktorom v procese aplikácie vybranej metodiky pre meranie st’ažností a reklamácií bolo zistenie, že evidovanie podaných reklamácií v príslušnom IS je nepostačujúce 
najmä $\mathrm{v}$ špecifikácií informácií o reklamovanej zásielke, z čoho jednoznačne vyplýva potreba rozšírenia zadávacieho formuláru IS. Ďalším problematickým miestom z pohl'adu vzniku nedostatkov a chybovosti či nekvality je fakt, že evidencia podaných balíkov I. a II. triedy je realizovaná v dvoch IS aj napriek ich on-line prepojeniu spôsobuje nedostatky a chyby v evidencii zásielok Najčastejším problémom boli vyplatenie/nevyplatenie dobierkovej sumy. Vel'mi často sa stáva, že pošta označí balík ako nedoručený v IS automatizácie priehradkových operácií, avšak d'alší IS vedený stav prevezme ako konečný. Až dodatočným zist’ovaním pošta odhalí, že balík je doručený, zmení jeho status v systéme $\mathrm{z}$ nedoručeného na doručený, avšak v IS sa nový status balíka vôbec neprejaví - pretože systémové nastavenie tohto IS je vždy dané prvým vykonaným záznamom, a d’alšie už systém ignoruje.

\section{Záver}

Pre zabezpečenie kvality poskytovaných služieb vykoná SP, a.s. a neustálu kontrolnú činnost', ktorá musí byt' $\mathrm{v}$ súlade $\mathrm{s}$ plánom kontrol, ale aj neplánovanými kontrolnými akciami. Dôležitou súčast'ou kontrolnej činnosti SP, a.s. je aj oblast' st'ažností/reklamácií. Vývoju st'ažností/reklamácií býva prikladaná vel'ká pozornost' z pohl'adu SP, a.s., pretože st’ažnosti/reklamácie od zákazníkov sú totiž považované ako najlacnejšia forma získavania informácií pre SP, a.s. o tom, ako zákazníci vnímajú kvalitu poskytovaných služieb. Okrem toho, že z pohl'adu opodstatnenosti sú st'ažnosti/reklamácie dôležitý ukazovatel' kvality poskytovaných poštových ale aj nepoštových služieb, pre riadiacich zamestnancov sú cenným zdrojom informácií o úrovni poskytovaných služieb z pohl'adu zákazníkov, o trendoch nespokojnosti zákazníkov ale aj o možných systémových nedostatkoch, čo je možné využit' pri navrhovaní zmien, pri plánovaní kontrolnej činnosti a jej zameraní.

Použitím vhodnej metodiky pre meranie a vyhodnocovanie st’ažností a reklamácií získava poštový podnik relevantné údaje o vnímaní kvality a spokojnosti zákazníka.

\section{Literatúra}

[1] ČOREJOVÁ, T., ROSTÁŠOVÁ, M.: Diagnostický postup v manažérstve kvality v pošte. 1. vyd. - Žilina : Žilinská univerzita v EDIS, 1999. - 94 s. : ISBN 80-7100-619-X

[2] ČOREJOVÁ, T., MADLEŇÁKOVÁ, L.: Quality of postal service and the possibilities of its evaluation [Kvalita poštovej služby a možnosti jej hodnotenia]. In: Quality management of services. - Žilina: University of Žilina, 2006. - ISBN 80-8070-573-9. Pp. 94-101.

[3] MADLEŇÁKOVÁ, L.: Možnosti elektronického monitorovania kvality poštových služieb. In: Perner's Contacts - ISSN 1801-674X. - 2007. - Roč. 2, č. 1 (2007), s. 76-83. Spôsob prístupu: http://pernerscontacts.upce.cz/PC_052007.pdf

[4] STN EN 14012 Poštové služby. Kvalita služby. Princípy vybavovania st'ažností

[5] STN EN 13850:2012 Poštové služby. Kvalita služby. Meranie času dopravy medzi koncovými bodmi pre jednotlivo podávané prioritné zásielky a zásielky prvej triedy

[6] Výročné správy Slovenskej pošty, a.s. $(2009,2011,2012)$

[7] Výročné správy Česká pošta, s.p. $(2009,2011,2012)$

[8] Zpráva o plnení povinnosti České pošty, s.p. v oblasti základních služeb za rok 2011. Červen 2012, [online]. [Dostupné na internete:

http://www.ctu.cz/cs/download/postovni_sluzby/zprava-plneni-povinnosti-ceske-posty2011.pdf

[9] http://www.posturad.sk/sk/staznosti-peticie

[10] Osobné konzultácie na sledovaných pobočkách

\section{Grantová podpora}

VEGA 1/0421/12 Modelovanie difúzie znalostí v podnikových hodnotových ret'azcoch

5/KS/2013 Uplatnenie metód viackriteriálneho rozhodovania a porovnávania poštových produktov 